\title{
Structure of Charnockitic basement in a part of the Krishna-Godavari basin, Andhra Pradesh
}

\author{
I V RADhakrishna MURThY* and S BAngaru BABU \\ Department of Geophysics, Andhra University, Visakhapatnam 530 003, India. \\ *e-mail: ivr_murthy@yahoo.com
}

\begin{abstract}
A regional magnetic survey was carried out over an area of $8000 \mathrm{~km}^{2}$ in Godavari districts of Andhra Pradesh, India, which is covered by the rocks of Eastern Ghat Mobile Belt (EGMB) viz., the Khondalitic series and Charnockites in the northern half and Permian to Mesozoic and Cenozoic sediments in the southern half, and forms a part of the Krishna-Godavari (K-G) basin. The survey brought out a strong NE-SW trending anomaly in the area covered by the rocks of Eastern Ghat Mobile Belt (EGMB), and a mild ENE-WSW trending anomaly in the area covered by the sediments of the Krishna-Godavari $(\mathrm{K}-\mathrm{G})$ basin. The NE-SW trending anomaly in the northern half could be attributed to the exposed/near surface Charnockite basement that has come closer to the surface as a result of Eastern Ghat Mobile Belt (EGMB) tectonics. Explanation of the mild ENE-WSW trending anomaly over the sediments of the Krishna-Godavari (K-G) basin required a faulted magnetic basement at depth downthrown towards the south. It is therefore concluded that the Charnockitic basement together with the Khondalite group of rocks which are folded and faulted during the different phases of tectonics of Eastern Ghat Mobile Belt (EGMB) extend into the Krishna-Godavari $(\mathrm{K}-\mathrm{G})$ basin and further, were involved in faulting during the phases of formation and sedimentation in the Krishna-Godavari $(\mathrm{K}-\mathrm{G})$ basin.
\end{abstract}

\section{Introduction}

The Eastern Ghat Mobile Belt (EGMB) is a prominent Precambrian orogenic belt that stretches intermittently for more than $900 \mathrm{~km}$ parallel to the east coast of India. The belt constitutes the most metamorphosed sector of the Precambrian rocks in the Indian shield. The geology of Eastern Ghats is so complex that a number of problems relating to the nature of the basement, origin of the constituent rocks and their structure remain imperfectly understood. The EGMB is believed to have undergone structural deformation during different times, being dominantly folded along NE-SW during the first major episode and subsequently crossfolded along ESE-WSW during a later episode (Narayana Swamy 1975; Sarkar 1980). Reviews of the tectonics of this mobile belt can be found in
Chetty and Murthy (1998), Ramakrishnan et al (1998) and others.

Although geological investigations in the EGMB and the east coast sedimentary basins are being increasingly undertaken, geophysical investigations have been limited to petroliferous sedimentary basins and areas of potential mineralization (for e.g., Suryabhanu and Murthy 1982), barring a few DSS transects (Kaila et al 1987a, 1987b, 1990). Radhakrishna Murthy and Rama Rao (2001) have carried out the first intensive magnetic survey in a part of the EGMB in Visakhapatnam, Vizianagaram and Srikakulam districts of Andhra Pradesh covering an area of $15,000 \mathrm{~km}^{2}$. They identified a couple of strong magnetic anomaly trends that ran initially in the NE-SW direction and later swerved along a N-S axis changing their trend to NW-SE. These anomaly trends extended into

Keywords. Eastern Ghat Mobile Belt; magnetic survey; magnetic basement; tectonics.

J. Earth Syst. Sci. 115, No. 4, August 2006, pp. 387-393

(C) Printed in India. 


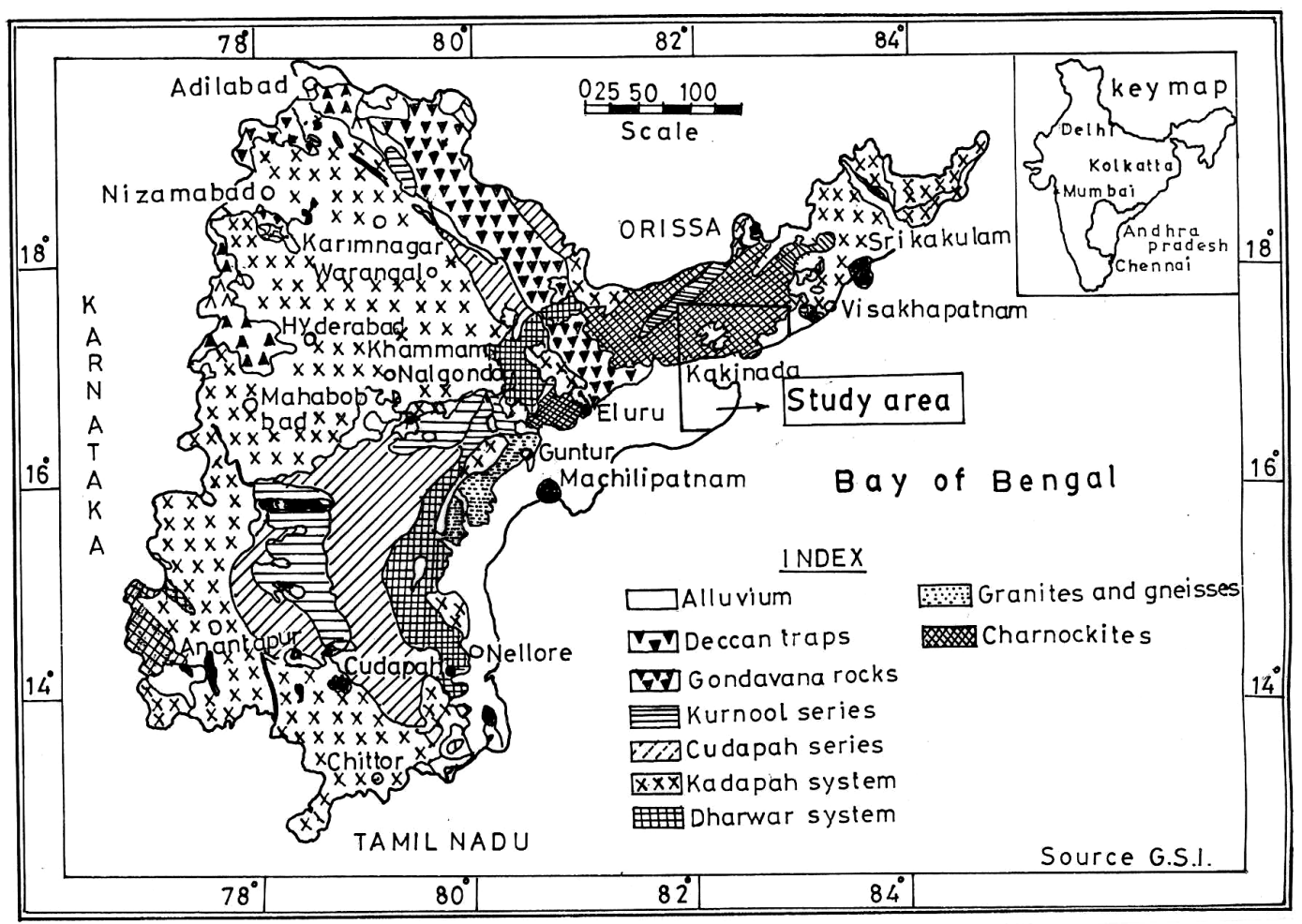

Figure 1. Location map of surveyed area (after Ramam and Murthy 1997).

the Bay of Bengal also. Radhakrishna Murthy and Rama Rao (2001) attributed these magnetic anomalies to structures in the Charnockitic basement below the exposed Khondalitic group of rocks, and explained the structures through the folding and cross-folding, and the associated faulting and movements of faulted blocks of EGMB.

In the present investigation an area of $8000 \mathrm{~km}^{2}$ of EGMB lying south of the area covered by Radhakrishna Murthy and Rama Rao (2001) was further investigated by a regional magnetic survey. The surveyed area covered the EGMB terrain in the northern half and a part of the petroliferous $\mathrm{K}-\mathrm{G}$ basin in the southern half and is aimed at tracing the extensions of the known magnetic anomaly trends of the adjoining area. It is concluded that the Charnockitic basement extends into the $\mathrm{K}-\mathrm{G}$ basin also below the Khondalitic group of rocks and both the rocks were folded and faulted during different stages of EGMB tectonics as well as sedimentation in the $\mathrm{K}-\mathrm{G}$ basin.

\section{Location and geology}

The area of the present regional magnetic survey falls in the Visakhapatnam and Godavari districts of Andhra Pradesh. It measures $8000 \mathrm{~km}^{2}$ and is bounded by latitudes $16^{\circ} 30^{\prime} \mathrm{N}$ and $17^{\circ} 30^{\prime} \mathrm{N}$ and longitude $81^{\circ} 45^{\prime} \mathrm{E}$ and $82^{\circ} 45^{\prime} \mathrm{E}$. Its location is shown in figure 1, with the general geology of the state of Andhra Pradesh.

The area shows a geologically contrasting setting between the northern half and the southern half (figure 1). North of $17^{\circ} \mathrm{N}$ latitude, the geological setting conforms strictly and typically to the Eastern Ghat Mobile Belt (EGMB). The EGMB is constituted with high grade granulite rocks of Khondalite, Leptynite, migmatised gneisses of granite composition and Charnockite. The EGMB shows poly-phase deformation which resulted in folds and cross-folds and sets of multiple faults. The rocks, particularly Khondalite which is the dominant rock type, shows pronounced gneissosity that trends NE-SW (varying about $22^{\circ}$ on either side) and this gives a regional tectonic trend to the belt. The rocks of the EGMB exposed north of $17^{\circ} \mathrm{N}$ latitude constitute hills of 600 to $800 \mathrm{~m}$ elevations, mostly made up of Khondalite suite of rocks with the NE-SW trend of gneissosity in the outcrops studied.

South of $17^{\circ} \mathrm{N}$ latitude, the geologic setting is that of the petroliferous Krishna-Godavari $(K-G)$ basin that developed over a Precambrian basement apparently belonging to the EGMB, and evolved during late Mesozoic with rifting and drifting of the Indian lithospheric plate. Before rifting, the Godavari basin was a major intra-cratonic basin within the Gondwanaland where sediments of $2.5 \mathrm{~km}$-thick from upper Carboniferous to Triassic 


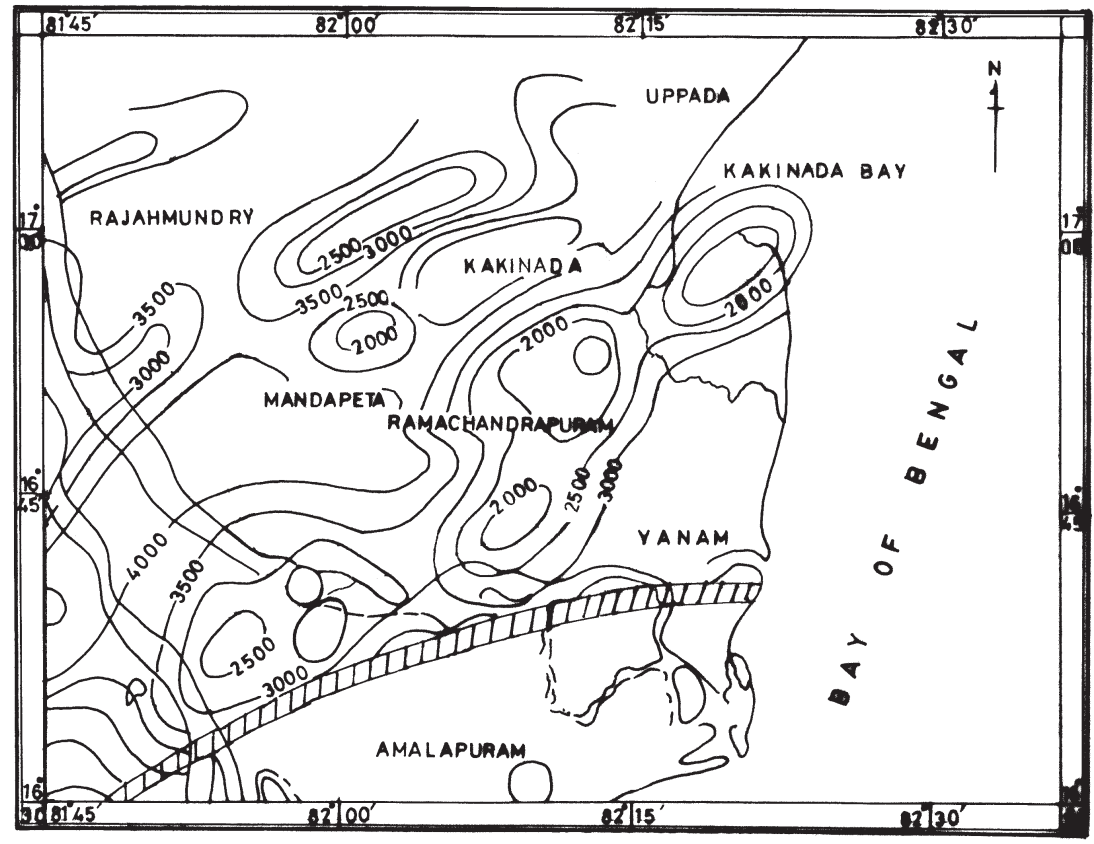

Figure 2. Basement ridges and depressions in the area (after Kamaraju et al 1998). T: Tanuku ridge, M: Mandapeta graben, D: Yanam-Drakharama high, MPFZ: Matyapuri-Palakollu Fault Zone (hatched line); the depth values are in meters. Contour interval is $500 \mathrm{~m}$.

were deposited in what is presently called Mandapeta trough. The architecture of the $\mathrm{K}-\mathrm{G}$ basin is made up of horsts alternated with sub-basins (figure 2), which trend NE-SW parallel to the tectonic trend of EGMB formed during the pull-apart stage of the east coast basins. The horsts of the $\mathrm{K}-\mathrm{G}$ basin are associated with faults of the same trend. The Precambrian faults reactivated from time to time resulting in differential movement of the faulted basement blocks, and this combined with syn-sedimentary subsidence and faulting particularly from near the coastal area close to Amalapuram seaward have given a complex sub-surface geologic setting to the basement and the $\mathrm{K}-\mathrm{G}$ basin.

The southern half of the investigated area falls wholly into the East Godavari sub-basin and also covers the NE tip of Tanuku horst (figure 2). The $\mathrm{K}-\mathrm{G}$ basin contains volcanic flows 600 to $900 \mathrm{~m}$-thick at the Cretaceous-Tertiary $(\mathrm{K}-\mathrm{T})$ boundary. A surface expression of a major postPalaeocene fault, the Matyapuri-Palakollu Fault Zone (MPFZ), which is slightly arcuate convex northward, shows an ENE-WSW trend. It caused tectonic readjustment of the faulted blocks in the basin.

\section{Magnetic survey}

The regional magnetic survey was conducted with a Proton Precession Magnetometer (courtesy NGRI) occupying a total of 880 magnetic stations.
The latitude and longitudes of the stations were determined through a GPS with internal and external antennas.

The survey was carefully planned such that the first station occupied on any day would be reoccupied at least three times on the same day for the purpose of diurnal correction. When this was not possible, the stations already covered were reoccupied. The Earth's normal magnetic field was calculated through IGRF and subtracted from the diurnal-corrected observed value. The accuracy of the magnetometer reading is $1 \mathrm{nT}$, while that of the reduced anomalies can be $\pm 5 \mathrm{nT}$.

\section{Magnetic anomaly map}

The magnetic anomalies of the area are shown in figure 3 contoured at 50 gammas. The map presents mostly gentle magnetic anomalies of the order of -50 to +150 gammas, except north of $17^{\circ} 15^{\prime}$. The anomalies south of $16^{\circ} 45^{\prime}$ are conspicuously negative and are of the order of 50 gammas and increase towards the north, until they encounter a sharp NE-SW trend north of $17^{\circ} 15^{\prime}$. In this NE-SW trend, passing through Rampachodavaram and Gokavaram, the anomalies vary sharply between 500 and -1000 gammas, with the negative magnetic anomalies being bordered on the south by linear positive anomalies, and developing into disjointed closures. Although observations could not be made north $17^{\circ} 30^{\prime}$ due to complex terrain and absence of motorable roads, the anomaly 


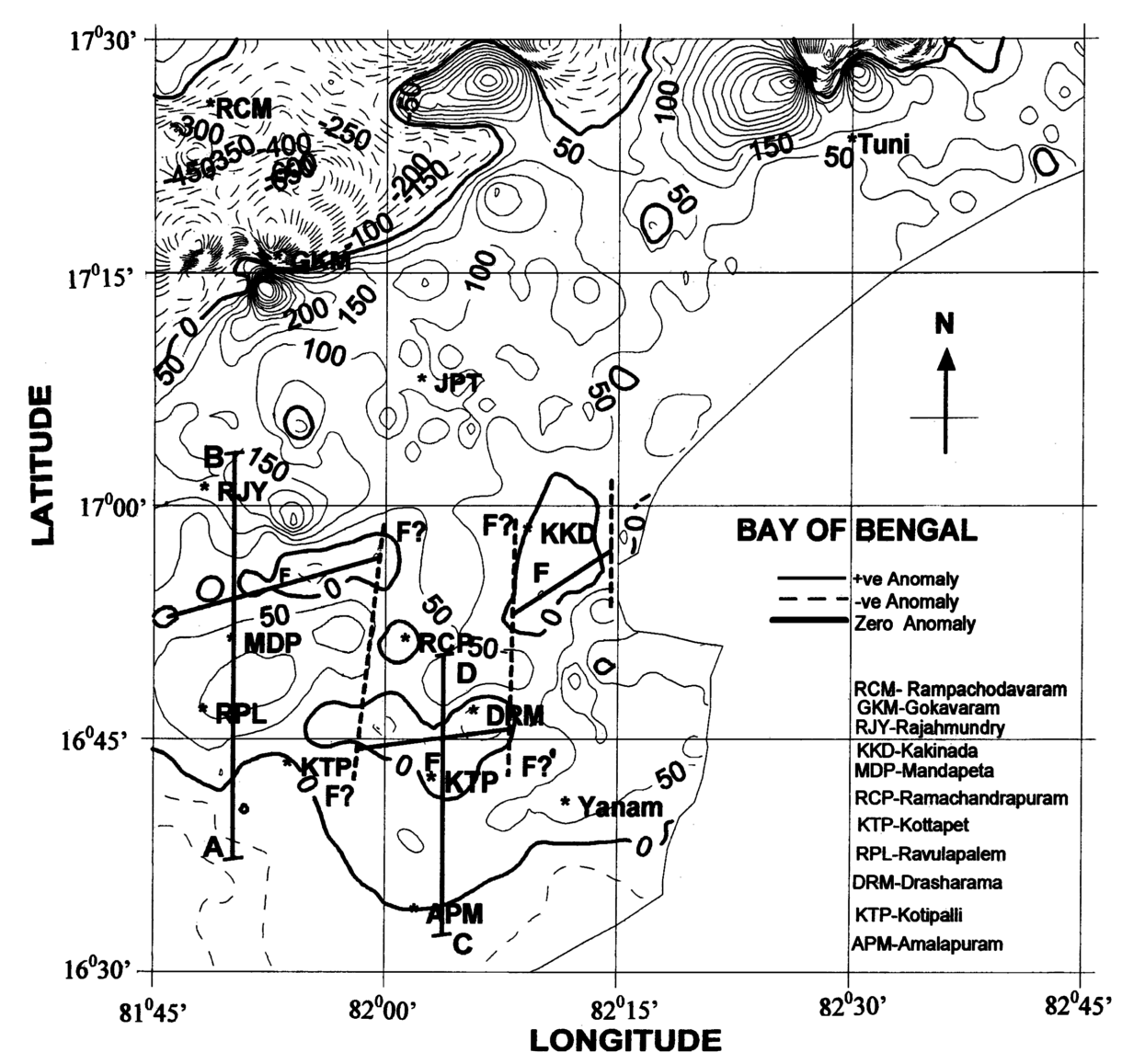

Figure 3. Magnetic anomaly map. Contour interval 50 gammas.

trend under discussion appears to be bordered on its north also by positive anomalies, as suggested by the few conspicuous linear positive anomaly contours on the $\mathrm{N}-\mathrm{W}$ corner at $17^{\circ} 30^{\prime} \mathrm{N}$ and $81^{\circ} 45^{\prime} \mathrm{E}$. This trend is found to be the extension of the one reported earlier by Radhakrishna Murthy and Rama Rao (2001) in the neighbouring area $\left(17^{\circ} 30^{\prime}-18^{\circ} 30^{\prime} ; 82^{\circ} 30^{\prime}-83^{\circ} 30^{\prime}\right)$. They could explain such trends in the Eastern Ghat terrain by invoking horst-like structures in the magnetic basement constituted by Charnockites, which become shallower and are exposed at several locations along the trends. Regional tectonics of the Eastern Ghats can easily explain such structures in the Charnockitic basement.

Though of a low amplitude, an interesting positive anomaly trend of 50 to 100 gammas, bordered on either side by magnetic lows, cannot be missed north of the latitude $16^{\circ} 45^{\prime}$. It is superimposed over the general increase of the magnetic anomalies from the south to north. This trend, initially striking ENE-WSW through Ravulapalem, discontinuously extends along the breadth of the map, often dislocated along N-S axes. The low magnitude and discontinuous nature of this anomaly suggest that the causative source is at depth and it has undergone strike-slip faulting.
The probable N-S faults as predicted by the dislocation of contours are marked in figure 3. This anomaly trend contrasts from the sharp one on the NE-SW, which has a higher amplitude, is negative in signature and is bordered by positive anomalies on either side.

\section{Inversion}

To ascertain the cause of the anomalies, a few profiles were constructed and inverted for several geophysical models as well as for structures on the magnetic interface, using the software developed by Radhakrishna Murthy (1998). Out of all the models, the semi-infinite horizontal plate was found to adequately explain the anomalies. The inversion scheme adopted was developed based on the Werner deconvolution technique and was designed not only to estimate the model parameters, but also the regional/background anomaly trend assumed to be linear. Interpretation of two typical profiles $\mathrm{AB}$ and $\mathrm{CD}$ (locations shown in figures 2 and 3) and their equivalent geological crosssections are presented in figures 4 and 5 . Inversion predicted in these profiles a background/regional anomaly increasing towards the north at the rate 

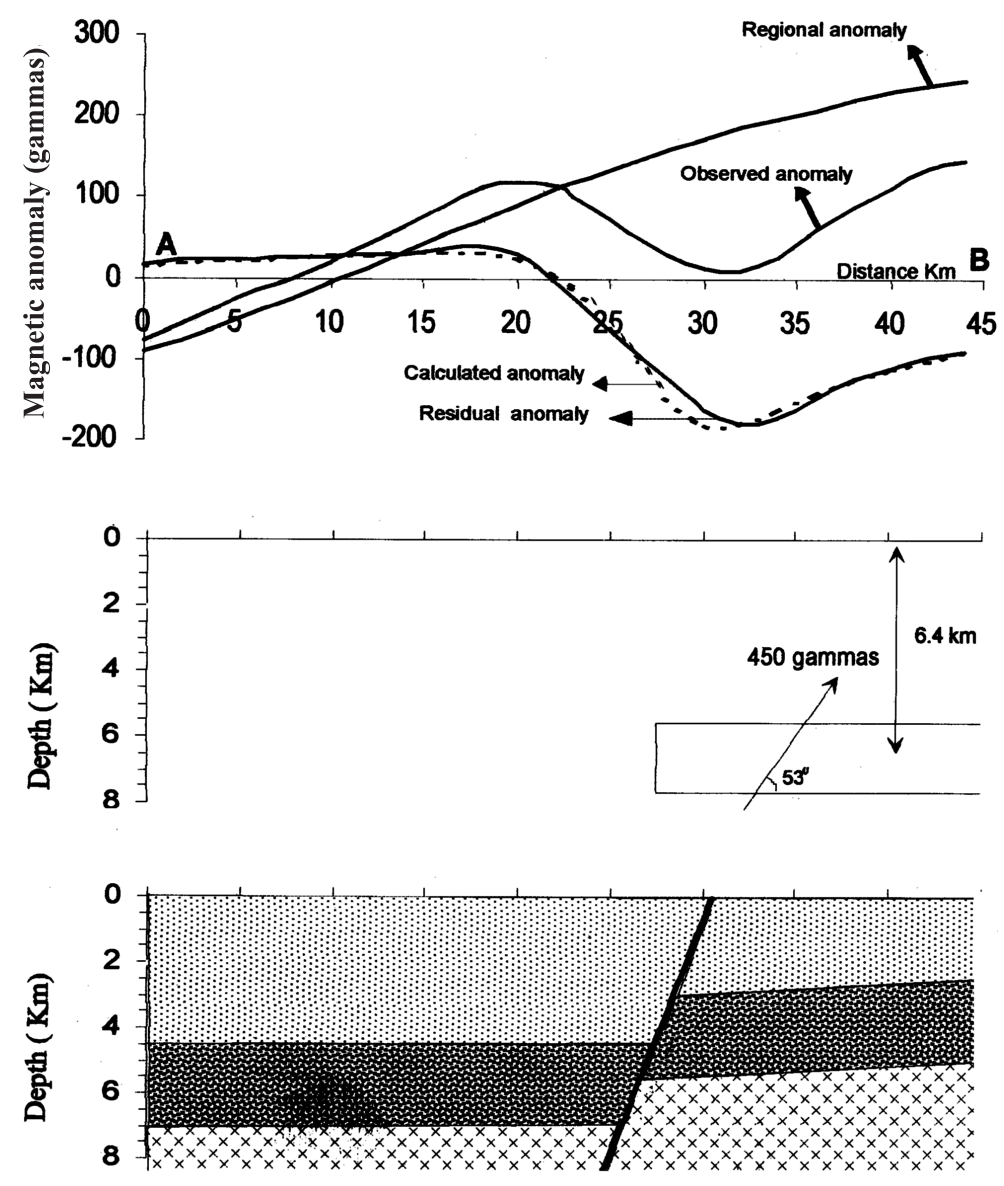

\section{Sediments Khondalites and Leptynites}

Figure 4. Inversion of the anomaly along profile AB and the probable subsurface geological cross-section.

of about 7 gammas $/ \mathrm{km}$ under profile $\mathrm{AB}$ and about 4 gammas $/ \mathrm{km}$ under profile CD. Although such gradients are not unusual in magnetic profiles, their magnitudes must be considered to be on the higher side in the present case in comparison with the low ranges of anomalies of 120 gammas in profile $\mathrm{AB}$ and 80 gammas in profile CD. The models derived for any assumed regional anomaly other than the one used, produced erratic geophysical models that did not comply with known geology. For example, a visual inspection of profile $\mathrm{AB}$ suggests a linear regional anomaly starting at -80 gammas at $\mathrm{A}$ increasing to +120 gammas at B. Such a regional anomaly produces a regional anomaly profile with a dominant positive maximum on the south followed by a dominant negative on the south. This regional anomaly needed a magnetic basement at a depth shallower than $3.0 \mathrm{~km}$, against the known thickness of sediments in the area which is at least $4.0 \mathrm{~km}$. Alternatively, this profile needed a faulted magnetic basement with an unusually smaller fault angle less than 30 degrees and large throws of $10 \mathrm{~km}$ and more. Also, the profiles, when tested for other models, required similar regional gradients to lead to convergence to any solution, although the models derived therefrom could not satisfy known geology. Thus assuming a strong linear background and invoking the model of semi-infinite horizontal plate are justified. Nevertheless, the strong regional anomaly can be adequately explained by the general south to north increase of the observed anomaly depicted in figure 3 . Such an increase may be due to the magnetic basement becoming shallower towards the north where it is exposed along the northern edge of surveyed area.

The inversion of profile $\mathrm{AB}$ predicted that the semi-infinite horizontal sheet responsible for the anomalies lies at a depth of $6.4 \mathrm{~km}$. A fault, whose throw is not larger than the depth of burial is treated as a semi-infinite horizontal sheet. Remembering that the calculated depth corresponds to the depth to the center of the sheet (not to the top), the top of the faulted anomalous body can be expected to be encountered not shallower than $4.2 \mathrm{~km}$, and its bottom not deeper than $8.5 \mathrm{~km}$. For a $1.5 \mathrm{~km}-$ throw, in particular, the depths to top and bottom 

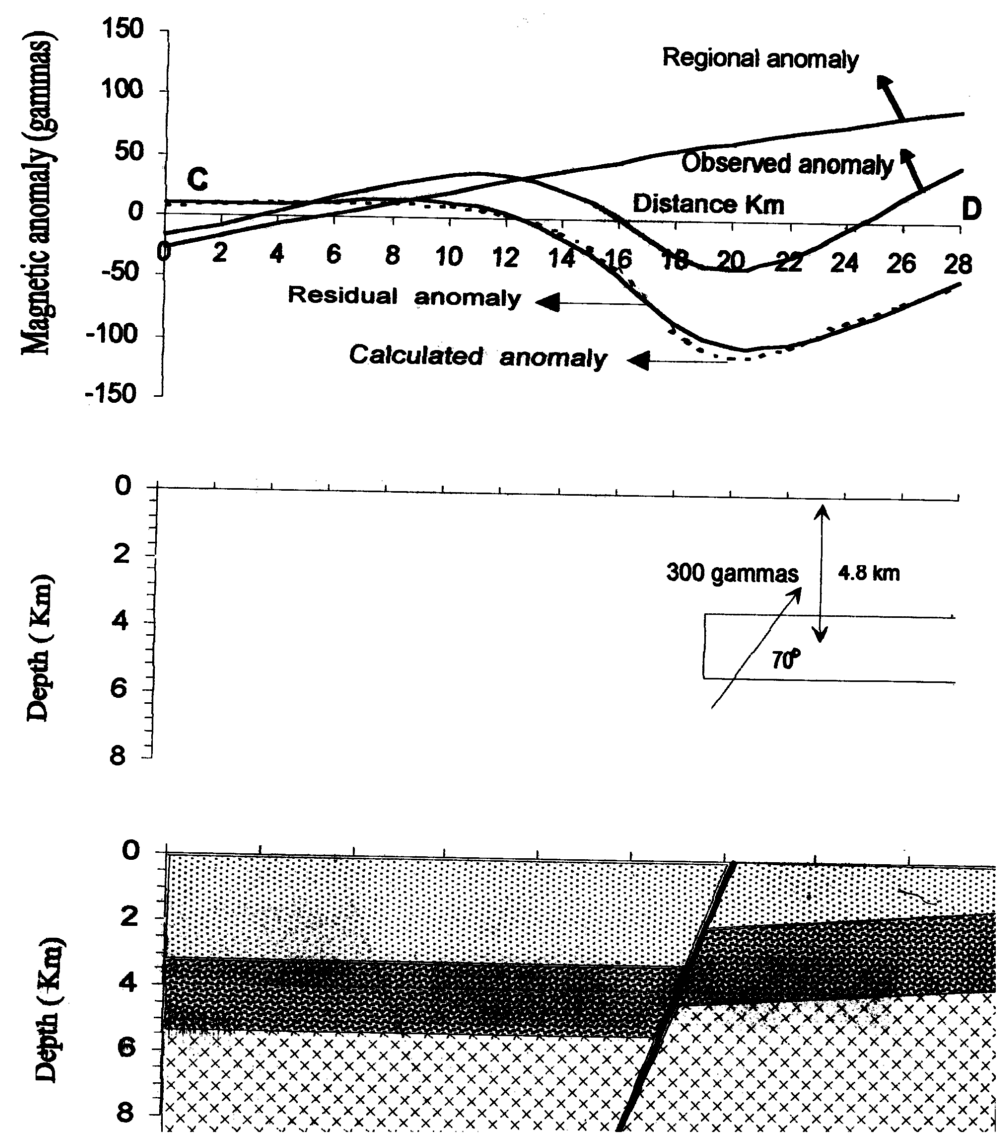

Sediments

Khondalites+ Leptynites $\left.x_{x}^{x} \times\right]$ Chamockites

Figure 5. Inversion of the anomaly along profile CD and the probable subsurface geological cross-section.

will be $5.6 \mathrm{~km}$ and $7.1 \mathrm{~km}$ respectively. For such a throw, the model requires an intensity of magnetization of 450 gammas, with an up dip of 53 degrees. These values are in agreement with the order of magnetization of Charnockites in the neighbouring area (Radhakrishna Murthy and Rama Rao 2001). Similarly profile CD requires the sheet to lie at the mean depth of $4.8 \mathrm{~km}$, putting the limiting depths to the top and bottom of the faulted anomalies body at $3.2 \mathrm{~km}$ and $6.4 \mathrm{~km}$ respectively. For an approximate throw of $1.0 \mathrm{~km}$, the faulted anomalous body should be at a depth of about $4.3 \mathrm{~km}$ on the north and at $5.3 \mathrm{~km}$ on the south. The magnetization of this faulted block is around 300 gammas dipping upwards at $70^{\circ}$.

Since the strong magnetic anomalies in the north could be authentically attributed to structures in the Charnockitic basement and the magnetization of the anomalous body correlates with that of the Charnockites in the neighbouring area, it can be concluded that the same magnetic basement extends south of $17^{\circ}$ also viz., into the $\mathrm{K}-\mathrm{G}$ basin. The mild anomaly under discussion is, then, due to the faulted magnetic (Charnockitic) basement.
The positions of the expected fault in the magnetic basement are shown in figure 3 by solid lines.

\section{Discussion}

Based on drilling data which extended to the basement presumably made up of EGMB, Prabhakar and Zutshi (1993), Ramamohana Rao et al (1996), Kamaraju et al (1998) and Rao (2001) discussed the tectonics of the $\mathrm{K}-\mathrm{G}$ basin, which is covered partly in the present survey. A portion of the basement map prepared by Kamaraju et al (1998) that covers profiles $\mathrm{AB}$ and $\mathrm{CD}$, is reproduced in figure 2, which shows that the largest thickness of sediment is around Amalapuram. Along profile $\mathrm{AB}$, the basement showed a change in depth by about $1.5 \mathrm{~km}$, as it passes in the south across a trough of $4500 \mathrm{~m}$ (called Mandapeta Graben) and a high (called Tanuku ridge) of $3000 \mathrm{~m}$ in the north. These values are lower than the values of $7.1 \mathrm{~km}$ and $5.6 \mathrm{~km}$ respectively for the depths of the interpreted magnetic basement for a throw 
of $1.5 \mathrm{~km}$. Similarly profile CD witnesses the basement of the Khondalitic rocks changing in depth from a deeper level near Amalapuram south of the MPFZ fault to about $3.5 \mathrm{~km}$ in the north. These values are again lower than the interpreted values for the magnetic basement with a throw of $1.5 \mathrm{~km}$. This clearly implies that the magnetic basement represented by Charnockite is much deeper and is overlain by $2.0 \mathrm{~km}$ thick Khondalite group of rocks.

The hypothesis of Narayana Swamy (1975) that the Khondalitic rocks of the EGMB are underlain by the Charnockitic basement was proved for the region north of $17^{\circ} 30^{\prime}$ by Radhakrishna Murthy and Rama Rao (2001) by their magnetic surveys. The present investigation clearly established that the Charnocktic rocks extend into the KG basin also, and is probably involved in faulting and folding simultaneously with the Khondalitic group of rocks during different stages of EGMB tectonics as well as sedimentation in the KG basin.

\section{Acknowledgements}

This work was carried out in the Emeritus Scientists Scheme awarded by the CSIR to the senior author; the financial support from the CSIR is gratefully acknowledged. Special thanks are due to Dr. V P Dimri, Director, NGRI, Hyderabad for lending a magnetometer for the fieldwork and to Prof. T Ramamohana Rao, retired Professor of Geology, Andhra University, Visakhapatnam for useful discussions and for improving the manuscript.

\section{References}

Chetty T R K and Murthy D S N 1998 Regional tectonic framework of the Eastern Ghat Mobile Belt: A new interpretation; In: Eastern Ghat Mobile Belt, Geol. Surv. India, Spec. Publ. 44 39-50.

Kaila K L, Murthy P R K, Rao V K and Venkateswara Rao N 1990 Deep Seismic Sounding in the Godavari graben and Godavari (coastal) India; Tectonophys. 173 307-317.
Kaila K L, Tewari H C and Mall D M 1987a Crustal structure and delineation of Gondawana basin in the Mahanadi delta area, India from deep seismic sounding; J. Geol. Soc. India 29 293-308.

Kaila K L, Tewari H C, Roy Chowdhury K, Rao V K, Sridhar A R and Mall D M 1987b Crustal structure of the northern part of the Proterozoic Cuddapah basin of India from deep seismic sounding and gravity data; In: Seismic studies of the continental lithosphere (eds) Asano S and Mooney W D Tectonophys. 140 1-12.

Kamaraju A V V S, Man Mohan M, Rao M R R, Powal D S and Yalamarty S S 1998 Mapping of basalt as an effective guide for the exploration of cretaceous hydrocarbon prospects in the north of Matyapuri fault in Krishna-Godavari basin; Bulletin of the ONGC Ltd. 35 195-204.

Narayana Swamy S 1975 Proposal for CharnockitesKhondalite system in the Archaean shield of peninsular India; Geol. Soc. India Misc. Publ. 23 1-16.

Prabhakar K N and Zutshi P L 1993 Evolution of southern part of Indian East Coast basins; J. Geol. Soc. India 41 215-230.

Radhakrishna Murthy I V 1998 Gravity and magnetic interpretation in exploration geophysics; Geol. Soc. India Memoir 40356.

Radhakrishna Murthy I V and Rama Rao P 2001 Magnetic anomalies and basement structure around Visakhapatnam, Vizianagaram and Srikakulam districts of Andhra Pradesh; Gondwana Res. 4 443-454.

Ramakrishnan M, Nanda J K and Augustine P F 1998 Geological evolution of the Proterozoic Eastern Ghat Mobile Belt; Geol. Surv. India Spec. Publ. 44 $1-21$.

Ramamohana Rao T, Venkateswara Rao Y, Prased G J S and Thirumala Rao P 1996 Tectonics of Chintalapudi and the adjoining sub-surface of Gondawana of Godavari valley and the East Coast of India; Proceedings, Ninth International Gondawava Symposia Oxford \& IBH. 2 755-781.

Ramam P K and Murthy V N 1997 Geology of Andhra Pradesh, Geological Society of India, Bangalore, India.

Rao G N 2001 Sedimentation, stratigraphy and petroleum potential of Krishna-Godavari basin, East Coast of India; AAPG Bulletin 85 1623-1643.

Sarkar S N 1980 Present status of Precambrian stratigraphy and geochronology of Peninsular India - a review; Indian J. Earth. Sci. 7 12-16.

Suryabhanu K and Murthy B G K 1982 Geophysical studies for manganese occurrence in Gharbham and adjoining areas, Visakhaptnam district, Andhra Pradesh, In: Proc. Vol (Unpubl) workshop on "Geoscientific aspects of Eastern Ghat Mobile Ghats", Geology Department, Andhra University, Visakhapatnam. 